\title{
A REVISION OF THE AMERICAN SPECIES OF PLATYMETOPIUS.
}

\author{
By E. P. Van Dużee, \\ Buffalo, N. Y.
}

The Hemipterous genus Platymetopius was founded by Burmeister in 1838 in his Genera Insectorum for the European rostratus H. S. and vittatus Fabr (=undatus DeGeer,) the former of which should doubtless be taken as the type. It is widely distributed in the palæarctic and nearctic regions. Twelve species have been recorded from the former and from the latter twenty-three are enumerated in the present paper. Three additional species have been described from tropical America, where the genus may be well represented.

This genus is easily distinguished from the allied Jassid genera by the long pointed vertex, the narrow front and the strong elytral venation. There are three anteapical and five apical areoles in the elytra of which the outer is broadly triangular; the second sector is connected with the branches of the first by two transverse veinlets and there is usually a series of eight or ten oblique veinlets crossing the costal areole. The elytra in the more typical species are more or less closely inscribed with fine brown or fuscous pigment lines and ornamented with a few oval or rounded whitish spots placed near the ends of the areoles of which those occupying the apex of the anteapical and the base of the apical are most regular and persistent. The angled base of the front usually has a concentric pale or white line a little below the sharp edge of the head where there is frequently a second line; these lines being accentuated by darker borders. In the paler faced species these lines may become obscure or entirely obliterated. In fully marked species there are usually five longitudinal pale vittre on the pronotum and about five white calloused spots on the margins of the scutellum of which three are on the angles of the posterior field. The characters of the genitalia are quite distinctive in some of the species but in most they run so close that they are of little value for diagnostic purposes.

I do not now like to express any very decided views on the phylogeny of this genus but in a linear arrangement of the genera I would certainly place it between Mesamia and Delto- 
cephalus. Through the former it is related to the Doryaini and through the latter with the Athysanini, while with this last tribe it is independently connected by genus Scaphoideus. I still adhere to the views expressed by me many years ago as to the value of the second cross nervure between the first and second sectors of the elytra as a diagnostic character in the Jassid genera. It is but one character among several which unite a fairly homogeneous group of genera with Mesamia at one extreme and Deltocephalus at the other. The form of the vertex alone can never be used for separating the Jassid genera into groups nor do I know of any other single character so available as is the elytral venation. That certain species of Athysanus or Eutettix show an occasional second cross nervure only proves to me that those genera have but recently developed from their parent stem and are still plastic. The whole group of genera included by me in the Deltocephalini and Athysanini seems now to, be in their ascendancy and rapidly developing in both species and genera, many of which have not yet become well differentiated.

In the preparation of this paper I have had before me representatives of all but two of the described American species, modestus and elegans. The latter however is a distinct species well known to me and it has been included in the synoptical table. Of the others I have examined the types of all but acutus Say, madgalensis Prov. and cinereus O. \& B., the two former of which certainly refer to our most abundant eastern species.

I wish here to extend my thanks to those who have assisted me with the loan of material. To Prof. Herbert Osborn I am indebted for a number of his types and the opportunity of examining all the material in his collection and in that of the Ohio State University at Columbus, Ohio; Dr. Ball has sent me his very valuable material in the genus including the types of the species recently described by him; and at the suggestion of Prof. Baker, Dr. Howard has kindly sent me the types of the three Baker species described in 1900 and with them examples of ten other species from the National Museum collection. In addition to this my own collection contains representatives of twenty species mostly in good series. From this material I have found it necessary to describe as new four species and one variety. 
In preparing the following dichotomous table of the species I have used the most available characters I could discover. Many of these characters are obscure or difficult to express in words which is especially true of the markings of the vertex although these markings seem to be good and constant characters. It must be borne in mind that the vertex in the female is always longer and more acute at apex than in the male. Unfortunately the type of temuifrons Baker was received too late to allow of its being included in the key to the species but its long vertex with a peculiarly broad and rounded apex and the brown face will readily separate it from verecundus to which it is most closely related.

\section{KEY TO THE SPECIES OF PLATYMETOPIUS.}

Elytra uniformly whitish-hyaline crossed by three narrow but usually well distinguished fuscous vittæ; oblique costal veinlets wanting; vertex rather short,

1. hyalinus Osb.

Elytra more or less hyaline, usually pigmented and veined or inscribed with fus. cous with the costal areole hyaline and crossed, at least at apex, by oblique fuscous veinlets; never uniformly hyaline with narrow transverse vittæ...

1. Elytra quite uniformly colored or subhyaline with at most but slight veining toward the apex; oblique veinlets of the costa wanting anterior to the anteapical areoles

-. Elytra white or whitish hyaline more or less clouded with fulvous cr cinereous and inscribed with fulvous-brown or fuscous, at times almost entirely fulvous or black; oblique veinlets at least indicated in the costal arecle

3.

2. Color a polished sub-hyaline brown; vertex large, parabolic, dull fulvous; clavus and a broad band across the anteapical areoles which extends back along the costa, whitish; face deep black with the edge and an angulate line white, conspicuous; length $4 \mathrm{~mm}$; inhabits California.

3. majestus Ball.

-. Color greenish or creamy white; vertex of the male short, about right-angled, of the female strongly produced, lineated at apex with brown and pale; elytra slightly infuscated at apex with about three oblique veinlets against the anteapical areoles; length $31 / 2-41 / 2 \mathrm{~mm} \ldots \ldots \ldots .2$. nigriviridis Ball.

3. Elytra but partially clouded and inscribed, marked with a conspicuous yellow dorsal stripe along the closed elytra; inhabits California.

4. elegans VanD.

-. Elytra variously clouded and inscribed but without a conspicuous pale dorsal vitta.

4. Vertex flat, Thamnotettix-like, not depressed nor channeled toward its apex, anterior margin rounded to the front; pronotum and elytra recalling Mesamia vitellina, wanting the white areolar spots of Platymetopius.

13. dorsalis Ball.

-, Vertex more or less channeled toward the apex which may be depressed or produced and a little elevated; anterior edge thin, acute or subacute . . .5.

5. Face pale or yellow, usually more or less infuscated at base and sides, the for-

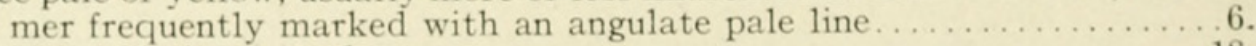

- Face entirely brown or fuscous . . . . . . . . . . . . . . . . . . . . . . . . .

6. Markings of the vertex in the form of lineations, usually a pale median line more distinct anteriorly and edged with brown, and a faint slightly

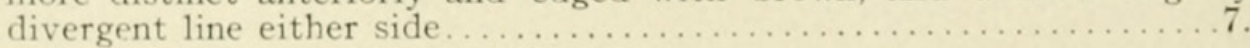


-. Pale markings on the vertex taking the form of a broken transverse vitta before the eyes, more or less complete, the median line short and apical. 15

7. Elytra subhyaline, either cinereous or fulvous, usually clouded and reticulated anterior to the anteapical areoles with the white areolar spots apparent; angular white line on the base of the front distinct (except in latus) . . .8.

Elytra fulvous and opake anterior to the anteapical areoles, the white areolar spots obscure in the female, obsolete in the male

8. General color cinereous with the elytral markings and areolar spots distinct; beneath mostly black; face distinctly infuscated at base and sides . . . . 9.

- General color fulvous with the elytral markings usually indistinct and the lower surface pale; face but slightly infuscated on the sides, the angular basal mark nearly obsolete.

10

9. Length $5 \mathrm{~mm}$; vertex of the male little longer than the width between the eyes, of the female somewhat longer; inhabits from Canada to Georgia.

5. acutus Say.

-. Length $4 \mathrm{~mm}$; vertex very long and pointed, at least twice as long as wide between the eyes; inhabits Florida.

9. slossoni VanD.

10. Face obscurely infuscated on the sides, the angular white line at base distinct.

11.

-. Face uniformly yellowish, the angular white line at base obsolete; vertex at least twice as long as wide between the eyes; elytral reticulations and areolar spots obsolete at least in the female........... . latus Baker.

11. Length at least $5 \mathrm{~mm}$.; general color fulvous

-. Length 31/2-4 mm.; color cinereous, usually tinged with greenish.

10. cinereus $\mathrm{O} . \& \mathrm{~B}$

12. Male plates short and broad, hardly passing the middle of the pygofers; areolar spots practically obsolete anterior to the anteapical areoles: general color darker, the males clearly marked

8. cuprescens Osb.

Male plates long triangular, but moderately exceeded by the pvgofers....13.

13. Last ventral segment of the female scarcely longer than one half its basal width; male plates narrow; pronotal vittæ usually distinct.

5. acutus var. dubius VanD.

Last ventral segment of the female long and narrowed to the nearly truncated apex; much longer than one half its basal width; male plates large and broad; pronotal vittæ obsolete

6. oregonensis Baker.

14. Larger, $4 \frac{1}{2} 2^{-5} \mathrm{~mm}$; valve of the male distinctly angled at apex.

-. Smaller, 3-4 $\mathrm{mm}$; valve of the male scarcely angled at apex.

5. Face pale or yellow, infuscated at the sides ......................

- Face entirely yellow, sometimes showing obsolete irrorations quite uniformly distributed

17 .

16. Vertex more obtuse; sides of the face distinctly and abruptly darker; the angulate pale line at base obvious across nearly the whole width of the face; vertex mostly black.

14. frontalis VanD

- Vertex more produced; face showing traces of darker irrorations especially at the sides; angulate basal line reduced to an angled transverse spot; vertex mostly white, the markings of the whole upper surface more strongly contrasting

15. nasutus VanD.

17. Vertex longer, about as in nasutus; pleuræ and legs mostly fuscous brown; inhabits Florida to Colorado and Mexico..........16. loricatus VanD.

-. Vertex shorter, about as in frontalis; pleuræ and legs whitish or mostly so: inhabits Jamaica..................... nanus VanD.

18. Male plates triangular, their apex acute or subacute; last ventral segment of the female long with its apical margin oblique either side of the middle which is distinctly produced and sometimes abruptly angled.

- Male plates short, transverse and rounded at apex, little exceeding the valve; last ventral segment of the female short, truncate, its hind margin a little sinuated 
19. Larger, $5 \mathrm{~mm}$.; white markings of the vertex scarcely forming a transverse vitta before the eyes, consisting of the apical line, a curved mark either side, and sometimes two dashes behind these, and four approximate marks on the base; inhabits eastern states and Canada .......21. obscurus Osb.

Smaller species, 31/2-4 mm.; markings of the vertex forming a transverse vitta before the eyes.

20. Vertex forming at least a right angle before, the apex subacute........21

Vertex short, rounded at apex................................... 23.

21. Vertex strongly produced, almost acute at apex, its length nearly or quite twice the width between the eyes; pale markings complete but not strongly contrasted; transverse vitta interrupted at the middle and sometimes on either side; inhabits Florida.

19. verecundus VanD

Vertex shorter, scarcely more than right angled at apex

22. Vertex paler at base shading to fuscous anteriorly; transverse vitta of four subequal white dashes; apical dash short, isolated; areclar white spots few but well distributed over the elytra; inhabits California and Mexico.

18. irroratus VanD.

-. Form of frontalis nearly; general color darker or blackish-fuscous; areclar white spots clustered abcut the apical transverse nervures; white markings on the vertex consisting of the apical line, a marginal line either side, two larger spots representing the transverse vitta, and two others at the base: inhabits Kansas.

20. scriptus Ball.

23. Anterior edge of the head marked with five uniform contiguous white spots; angled white line on the base of the front represented by a small but distinct transverse spot; inhabits Jamaica

23. brevis VanD.

-. Anterior margin of the head marked with a white apical point and an obscure pale patch either side about the ocelli; white mark on the base of the front represented by a short slender arcuated line; inhabits Guatemala.

22. osborni VanD

\section{Platymetopius hyalinus Osborn.}

Ent. News, xi, p. 501, 1900.

This insect is quite aberrant in its genus by its uniformly whitish hyaline elytra crossed by three narrow fuscous bands. Prof. Osborn described it from a series taken from an imported tree at Washington, D. C., and strongly suspected that it might be an exotic form introduced with material added to the Botanical Gardens there. In that case it probably has become acclimated as Mr. C. W. Johnson has sent me a specimen he took near Philadelphia.

\section{Platymetopius nigriviridis Ball}

Ent. News, xx. p. 163, 1909.

Another very distinct little species from California. It is of a pale straw color tinged with green especially on the head, anterior margin of the pronotum and abdomen. On the elytra there is a longitudinal line on the clavus, some of the discal nervures near the apex, about four of the oblique costal veinlets posteriorly, and a spot at the apex of the inner apical areole blackish. Face immaculate. Vertex of the male short, about right-angled at apex; of the female strongly produced but little shorter than in slossoni. The variety dixianus Ball is still 
paler with the vertex of the female shorter and similarly lineated with fuscous at apex. This variety, of which I have seen only the types, is from Utah.

\section{Platymetopius majestus Ball.}

\section{Ent. News, xx. p. 164, 1999}

A small but very distinct species thus far reported only from California. Its deep black face marked with a white basal edge and concentric line, the large pale yellowish parabolic vertex and the brownish iridescent and uninscribed elytra make its identification easy. I have seen only the types which were kindly loaned to me by Dr. Ball.

\section{Platymetopius elegans Van Duzee.}

Ent. Americana, vi, p. 94, 1890.

In this species there is a broad yellowish dorsal stripe from the middle of the vertex to the tip of the clavus. The corium is brownish-cinereous obscurely banded with whitish hyaline, the cinereous areas are minutely inscribed with fuscous, the apical submargin and some of the adjacent nervures are heavily embrowned and the clavus and disk of the corium are sprinkled with obscure rufous dots. The lower surface is yellowish with the base of the face cinereous and the angled pale line distinct. The vertex of the female is about one half longer than the width between the eyes. Length $5 \mathrm{~mm}$. I have seen only the unique female type which was from California but among my Florida captures was one apparently scarcely mature specimen showing a similar yellow dorsal vitta, which I cannot identify with this species. It may represent a still undescribed form.

\section{Platymetopius acutus Say.}

J1. Acad. Nat. Sci., Phila., vi, p. 306, 1831: Compl. Writings, ii, p. 382.

Platymetopius magdalensis Prov. Pet. Faun. Ent. Can. iii, p. 275, 1889.

This, our most widely distributed Platymetopius, seems to be the stem form from which have branched off most of the closely allied species found in this country, to all of which it is connected by certain variable characters. Its typical form, agreeing perfectly with Say's description, is found throughout the middle and northern states but in one form or another it occurs from the Atlantic to the Pacific coasts and from northern Quebec and British Columbia to, or nearly to the gulf coast. The typical form may be characterized as follows:

Vertex in the male a very little longer than broad between the eyes, in the female distinctly longer. Color: Vertex fulvous-brown finely 
irrorate with testaceous forming a longitudinal line next each eye and another midway between that and the median sulcus; a line at apex, an oblique mark either side of this and four marks on the basal margin white bordered with piceous black. Pronotum fulvous-brown, closely, confluently irrorate with testaceous-white and showing five whitish longitudinal vittæ more or less conspicuous. Scutellum fulvous with four spots on the anterior field and the three angles of the posterior field whitish, outlined in black, the disk of the anterior field sometimes variegated with pale. Elytra white, rather closely inscribed with fulvous brown; nervures darker brown; costal area white crossed by nine or ten heavy oblique veinlets; round areolar white spots most conspicuous in the apex of the anteapical areoles, the base of the apical, and near the tip of the claval. Face light yellow, abruptly shading to fuscous on the base of the front and outer half of the cheeks, the former marked with a white angled line and a more slender one follows close under the anterior edge of the vertex; the lower continued as a longitudinal line behind the eyes. Beneath and legs deep black, more or less varied with whitish, the tibiæ white dotted with black at the base of the white spines. Genital characters. Male: Last ventral segment short, broadly and very obtusely excavated. Valve large obtusely triangular, apex rounded. Plates triangular, exceeding the valve by about its own length, their sides rectilinear or more generally slightly convexly arcuated to an obtuse apex, sometimes a little concave with their apex subacute; closely fringed with stiff bristles. Pygofers narrow, distinctly exceeding the plates. Female: Last ventral segment scarcely longer than one half its basal width, moderately compressed suggesting a median carina; viewed from directly below the hind margin is broadly rounded; oviduct scarcely exceeding the pygofers. Length about $5 \mathrm{~mm}$.

Toward the north and west this species varies to a lighter almost fulvous color with little if any black beneath, the face is paler, scarcely shading to darker on the sides of the cheeks, and the vertex is more strongly produced, at least one half longer than broad between the eyes. I call this variety dubius to distinguish it from the typical form with which it is connected by almost insensible gradations. It in turn forms a connecting link with oregonensis, which however I believe to be a distinct species. I have listed this species as latus in Canadian Entomologist, x1, p. 157, 1908.

\section{Platymetopius oregonensis Baker.}

Can. Ent, xxxii, p. 49, 1900.

This species was described from two males from Oregon but Dr. Howard has sent to me from the Baker collection one male and one female marked as types. These agree in every particular with material in Dr. Ball's collection and my own from California, Utah, Colorado and New Mexico. In the male the 
vertex is shaped almost exactly as in the male of acutus, but it is shorter than in the female acutus with which sex I assume Prof. Baker may have compared his specimens. The female has a much longer vertex, its length being somewhat more than twice its width between the eyes. In color this species is still paler than in the variety dubius of the preceding species. It is of a light fulvous, paler and almost immaculate beneath; the face is pale with but very faint infuscation on the base of the front and sides of the cheeks but with the angular white lines on the former distinct.

This species is best distinguished by the form of the genital pieces: The valve of the male is more angled and subacute at apex; the plates are larger with their outer margins distinctly concavely arcuated and their apices a little divergent and subacute. The last ventral segment of the female is conspicuously longer and narrower than in acutus with its apex slightly subangularly produced.

\section{Platymetopius latus Baker.}

Can. Ent. xxxii, p. 50. 1900.

I have one female of this species taken by Mr. W. J. Palmer of this city at Quinze Lake, Quebec, which agrees perfectly with Prof. Baker's Colorado type received from Dr. Howard. It may be distinguished by its fusiform shape, narrow pointed head with a vertex twice as long as its width between the eyes, the broad flaring elytra, the almost uniform coloring which is fulvous-brown above, without irrorations on the vertex, pronotum and scutellum, and almost without elytral reticulations or white areolar spots, the nearly concolorous nervures, those of the costal areole being a little more distinct, and the uniformly pale yellowish-testaceous coloring beneath with the base of the front darkened only at the extreme tip and not showing the angular white mark. Genital characters nearest to those of acutus; the last ventral segment a little more angled and the pygofers smaller. This is a rare species and probably is confined to northern Canada and the higher regions of the Rocky Mountains.

\section{Platymetopius cuprescens Osborn.}

20th Rept. N. Y. State Ent. p. 517, 1965.

Another closely allied species which comes nearest to acutus but has a longer and sharper vertex, about as in dubius and oregonensis; the elytra are more infuscated with but slight traces 
of the white areolar spots. The face is pale yellow, but little darkened on the base of the front and sides of the cheeks, with the pale angular line distinct. The genital characters of the female are very close to those of acutus, but the last ventral segment is more carinated with its apex distinctly notched when viewed from below. In the male these characters are very distinctive. Last ventral segment longer, not shorter, than the preceding; valve shorter; plates much shorter, rounded, about two thirds the length of the valve; pygofers broad, exceeding the plates by about the length of the latter and similar to them in color and texture. Prof. Osborn's type was taken by me at Phoenicia, N. Y., I have taken another female at Niagara Falls and a male at Boulder, Colorado, and another at Ogden, Utah, and Mr. Palmer took one at Quinze Lake, Quebec.

\section{Platymetopius slossoni n. sp.}

Very close to acutus but smaller with a longer and more acute vertex and shorter male pygofers. Length $4 \mathrm{~mm}$.

Vertex long and acute at apex, still longer than in oregonensis and latus rather more than twice as long as wide between the eyes and obviously longer than the pronotum and scutellum together; marked with three pale longitudinal lines as in acutus; the lateral curved, becoming approximate and parallel for a short space at base. Face light yellow with the angled base of the front and sides of cheeks broadly distinctly infuscated, the former with a very distinct acutely angled concentric white line which is projected to the apex of the head and is strongly reproduced behind the eyes. Pronotum with the longitudinal vittæ distinct as in acutus. Beneath and abdomen dark fuscous; in the female obscurely marked or irrorate with pale in places; last ventral segment shaped as in acutus, whitish at base with about four black ligulate marks on the basal margin. In the male the pectus and abdomen are deep black, obscurely marked with pale on the venter and at the tip of the valve; last ventral segment angularly but not deeply emarginate; valve triangular, subacute at apex; plates rather broad-triangular, on their sutural margin as long as the valve, their outer edges moderately sinuated and fringed with bristles, their apex a little narrower than in acutus; pygofers slightly but distinctly shorter than the plates which they scarcely exceed at the sides.

Described from one pair taken at Jacksonville, Fla., in May, 1910, by Mrs. Annie Trumbull Slosson whose enthusiasm and industry have added so much to our knowledge of the insect fauna of Florida and other parts of the eastern United States. I took a good series of what is certainly the same species at Crescent City, Sanford, Sevenoaks and Ft. Myers, Florida. 
They differ only in being slightly larger and paler. This species is very close to acutus with which the typical form is almost identical in color and markings but its small size, remarkably long and acute vertex and the short male pygofers preclude its reference to that species.

\section{Platymetopius cinereus Osborn \& Ball.}

Proc. Iowa Acad. Sci. iv, p. 193, 1897.

This is a very small and somewhat greenish species with a vertex formed about as in acutus; face greenish-white, very slightly infuscated on the base of the front where the angular white line is distinct; markings on the vertex and pronotum nearly obsolete but the five pale vittæ of the latter are generally discernable; abdomen mostly black in the male, rarely so in the female; elytra closely but lightly reticulated. Last ventral segment angularly produced in the female; valve of the male obtusely triangular; plates nearly as long as the valve on their suture, triangular, blunt at apex, considerably exceeded by the pygofers.

This, one of our smallest species, is found throughout the warmer portions of the central and southern states from Iowa. to Florida.

\section{Platymetopius angustatus Osborn.}

20th Rept. N. Y. State Ent., p. 518, 1905.

Prof. Osborn has very kindly sent me one of his male types and I have examined the female in his collection. This is the snallest species known to me and has been reported from the type locality only: Long Island, N. Y. The female is distinctly larger with a longer vertex than the male. It has a light greenish color with coppery reflections; the round areolar spots of the elytra are confined to the apical and anteapical areoles; the costa is hyaline with the oblique veinlets dark and the abdomen is marked with black. The male is smaller with a much shorter vertex; its color is a bright fulvous becoming yellowish on the head; the elytra are subopake, almost unicolorous on their base but becoming recticulated with brown on their apical and anteapical areoles where the round white spots are fairly distinct; oblique veinlets of the costal areole almost obsolete. In both sexes the base of the front is feebly infuscated with the pale angular line discernible. 
Last ventral segment of the female rounded. Valve of the male large scarcely angulate at apex; plates triangular, on their suture shorter than the valve; terminated by the long setæ; the brown apex of the pygofers much surpassing the plates.

\section{Platymetopius fulvus Osborn.}

20th Rept. N. Y. State Ent., p. 519, 1905.

This insect has about the form and size of frontalis but it is of a bright fulvous color with the elytra mostly opake and the markings almost or quite obliterated from the base nearly to the apex of the ante-apical areoles; vertex and scutellum more yellowish with indistinct pale vermiculate lines; oblique costal veinlets brown on a concolorous ground; face almost uniformly pale yellow with the basal angular pale line rarely indicated.

Last ventral segment of the female rounded behind with a blackish arcnate mark either side which gives it the appearance of being strongly produced on the middle. Valve of the male ovate-triangular, its margins arcuated to the obtuse apex; plates large, triangular, exceeding the valve by its own length; strongly ciliate on their outer margins; pygofers slender, longer than the plates.

Prof. Osborn's types were from Cold Spring Harbor, Long Island. N. Y. About Buffalo it is not uncommon among the hills at Colden and Gowanda and it has been reported from Pennsylvania and Ohio.

\section{Platymetopius dorsalis Ball.}

Platymetopius frontalis var. dorsalis Ball. Ent. News, xx, p. 164, 1909.

I cannot agree with Dr. Ball in placing this as a variety of frontalis. It seems to me very distinct and withall a difficult species to place. It is fulvous and pale yellow in color and has much the aspect of a small Mesamia vitellina but it has the vertex of a Thamnotettix and the front of a Platymetopius, to which genus I think it is most closely allied by its venation and structural characters. The anterior edge of the head is obtusely rounded as compared with the allied species. The lower surface, vertex and scutellum are pale yellow and immaculate. The pronotum and elytra are bright fulvous with coppery reflections, with the sides of the pronotum, costa at base, apical areoles and a vague saddle across the apical half of the clavus yellowish. I have seen only the unique type from Kansas kindly loaned to me by Dr. Ball. 


\section{Platymetopius frontalis Van Duzee.}

Can. Ent. xxii, p. 112, 1890.

Common and widely distributed throughout a great part of the United States and Canada. This species may be distinguished by its stout form, short vertex and blackish color both above and below, with a clear yellow face which becomes infuscated at each side but scarcely at the pointed base where the angled lines are but poorly distinguished. The vertex has a white median dash at apex and a transverse vitta of similar marks across the disk before the eyes, more or less conspicuous. The pronotum sometimes shows faint traces of the five pale vittæ and there may be some white marks on the scutellum forming two broken longitudinal vittæ. Elytral areoles with pale reticulations about their margins, sometimes nearly obsolete in the males; round areolar spots well developed and conspicuous; costa white, the oblique veinlets heavy; apical areoles generally infuscated beyond the white basal dots, the extreme edge clear white. Male genital characters about as in fulvus; the valve broader and more rounded and the plates a little shorter; last ventral segment of the female short and broadly rounded on the apical margin. Dr. Ball has sent me for inspection a typical example of frontalis taken by Prof. Gillette in Mexico.

\section{Platymetopius nasutus Van Duzee.}

Bul. Buf. Soc. Nat. Sci. viii, No. 5, p. 64, 1907.

While very close to frontalis I believe this a sufficiently distinct species. The vertex is obviously longer and more pointed and there is much more white in the coloring of the upper surface. The vertex is mostly white with the apex and a transverse eroded vitta black, the former with a median line and two oblique dashes white; the pale basal portion is veined with fuscous and the white median area is crossed by a black longitudinal line either side of the middle; the pronotum is irrorated with white and fuscous with the anterior margin and depressed sides mostly white and the longitudinal vittæ scarcely indicated. The elytra are white with a few fulvous-brown areas in the areoles and with fuscous reticulations more or less extended, the white areolar spots being much obscured. Beneath black with the tibiæ and tarsi white, dotted with black; the femora sometines largely invaded with white. 
In this species the face while mostly yellow shows a strong tendency to a uniform fuscous irroration which becomes more conspicuous laterally (thus forming a connecting link with the group of brown-faced species), and the angled base may also be darkened, with a transverse crescentic white mark. The male plates are proportionately a little larger and more obtuse at apex than in frontalis and the last ventral segment of the female is shorter and more angled. The types of this species were from Jamaica and Colorado and I have seen others from California.

\section{Platymetopius loricatus Van Duzee.}

Bu1. Buf. Soc. Nat. Sci., v., p. 205, 1894

Allied to nasutus but sometimes smaller and showing strong indications of the frontal irrorations found in fuscifrons. Face in typical examp'es entirely pale yellow. Vertex shorter than in nasutus but longer than in frontalis; its markings substantially as in frontalis but here the white vitta consists in great part of two longer approximate and dislocated white dashes and a few minute irrorations, the base with two median white dashes. Pronotum with the five pale vittæ fairly distinct. Elytra mostly blackish as in frontalis but with the white areolar spots smaller and fewer anteriorly. Face frequently showing strong indications of fuscous irrorations, especially toward the base of the front where there is then a short angled white mark. Last ventral segment of the female short, its hind margin hardly angled at the middle, the lateral angles rounded. Valve of the male short and rounded or very feebly angled; the plates broadly but acutely triangular, scarcely longer on their suture than the valve; slightly exceeded by the pygofers. Described from California but I have seen others from Colorado, Florida, Orizaba, Mexico, and Gualan, Guatemala.

\section{Platymetopius nanus Van Duzee.}

Bul. Buf. Soc. Nat. Sci, viii, No. 5, p. 65, 1907.

Very close to loricatus but the colors are paler with the white elytral spots less distinct, the pleura are yellow with a brown cloud anteriorly, not black as in loricatus, and the vertex is a little shorter but similarly marked. The last ventral segment of the female is more produced. In the male the last ventral segment is subangularly excavated behind; the plates also are larger and white, surpassing the apex of the pygofers which is not the case in loricatus. 
The aspect of these two species and the next shows a greater difference than is sustained by their structural characters and it is possible, but I hardly think likely, that material from intermediate localities may necessitate merging them in one. The smaller namus has thus far been found only in the island of Jamaica.

\section{Platymetopius irroratus n. sp.}

Differs from loricatus in being paler in color and generally smaller and in having the hind edge of the last ventral segment of the female distinctly angled either side and the plates of the male proportionately shorter but equally acute at apex leaving the margins more deeply arcuated. In this form the face is always more or less irrorated with brown or fuscous or at times entirely pale brown irrorated with pale. In the paler individuals the facial irrorations are always more dense toward its angled base where the pale line is distinct. The vertex is somwehat shorter than in loricatus and the elytra are cinereous instead of almost black as in that species. It is close to brevis but may be distinguished by the longer vertex which is darkened at apex and marked with four white dashes as in loricatus. The genital characters are also quite different from brevis. Length $4 \mathrm{~mm}$.

Dr. Ball has sent me a long series of this species taken at Chino, Riverside, Pasadena and San Diego, California, Phoenix, Arizona, and Ti Juana, Mexico.

\section{Platymetopius verecundus n. sp.}

Allied to irroratus and obscurus but with a longer vertex than in either. Length $31-2$ to $4 \mathrm{~mm}$.

Vertex about as in oregonensis, much produced and acute but distinctly shorter than in slossoni; in the female about twice as long as wide between the eyes. Clypeus much constricted near the base with its apex produced and rounded as in the allied species. Hind margin of the last ventral segment of the female distinctly angled and slightly produced at the middle and more obscurely angled on either side. Last ventral segment of the male subangularly emarginate; valve large, scarcely angled at apex; plates as in loricatus, a little longer than in irroratus and smaller than in scriptus and obscurus.

Color fulvous-brown with rather strong ornamentation. Vertex marked as in the allied species, the pale apical line more developed; transverse pale vitta sometimes almost entire or broken only by the fulvous median stripe and a brown line near it on either side, or there may be a second interrupting line exteriorly; base with a white median vitta bisected by a fuscous longitudinal line and sometimes terminated outwardly by a similar line. Pale vittæ of the pronotum distinct. 
Scutellum distinctly fulvous with the extreme angles and two vittæ irrorate with white. Elytra strongly inscribed; the areolar white spots distinct; costal areole whitish with the oblique veinlets strong; apical areoles narrowly fuscous next to the slender white apical margin. Front fulvous-brown, obscurely irrorate with pale, the white angular mark on the base of the front well developed and reaching about one half way to the eyes. There are two white lines beyond the eyes and an obsolete oblique one at the upper angle of the lorx; pectoral pieces fulvous-brown, conspicuously paler beneath. Abdomen fuscous or brown, varied with pale. Legs pale dotted with fuscous.

Described from numerous examples taken by me in Florida and listed as "obscurus Osb.?" in my report on the Hemiptera taken at that time. The exact localities represented are Crescent City, Sanford, Sevenoaks, Clearwater and Estero. This species with nanus from Jamaica, irroratus from Mexico and scriptus from Kansas form a puzzling group of very closely allied forms which run into loricatus on one hand and obscurus on the other. Their genital characters vary slightly but are not sufficient for separating them. Students with "lumping" proclivities will doubtless place them as varieties of a single species.

\section{Platymetopius scriptus Ball.}

Ent. News, xx, p. 165, 1909.

Male: A little larger and darker with a shorter vertex than in the preceding two species. Closely allied to frontalis but with a brown front and differently marked vertex. Last ventral segment nearly as long as the preceding, broadly angularly excavated behind and distinctly carinate on the median line; valve large, produced but scarcely angled at apex; plates large, subacute at apex, sides nearly straight; on their suture much shorter than the valve; considerably surpassed by the pygofers. Color blackish fuscous, nearly as dark as in frontalis, paler on the scutellum; white areolar spots present in the apex of the anteapical and base of the apical areoles, elsewhere usually wanting. Face brown, coarsely irrorate with pale, the angular basal mark distinct. Pectus, abdomen and legs black; tibiæ mostly white dotted with black; median apical line and anterior edge of the vertex white; the latter forked about the ocelli and connected with a squarish white spot indicating the transverse vitta of loricatus; basal white dashes usually connecting with another exteriorly forming an irregular pale patch. Scutellar angles more or less conspicuously fulvous. Length $4 \mathrm{~mm}$.

Known to me only from the five type specimens kindly loaned to me by Dr. Ball. 


\section{Platymetopius obscurus Osborn.}

Ohio Nat. v. p. 274, 1905.

This species very closely resembles acutus in size, color, markings and shape of the vertex. The face however is fulvous-brown, coarsely irrorate with paler; the valve of the male is more angled, the plates are smaller and the hind edge of the last ventral segment of the female is more transverse and angled on either side. Length $5 \mathrm{~mm}$.

Described from New York, Pennsylvania and Ohio. Mr. Palmer found it abundant at Lake Temagami, Ont., and Quinze Lake, Quebec. I took it at Sharon and Ipswich, Mass., and have examined others from Georgia.

\section{Platymetopius osborni n. sp.}

Near brevis but larger with a shorter vertex. Length 4 to $41-2 \mathrm{~mm}$. Vertex scarcely longer than its basal width; anterior margin rounded, the angle at apex lardly indicated. Front broader than in brevis, its sides parallel or nearly so to the superior tip of the loræ, then abruptly narrowed to the clypeus. Genital characters substantially the same as in the allied species except that the last ventral segment of the male is shorter and the pygofers are longer, surpassing the plates. Last ventral segment of the female distinctly angled at about the middle of the latero-posterior margins where they are practically rectilinear in brevis. Color about as in brevis becoming paler in some females. Vertex fulvous-brown varied with darker, base with four pale marks; a line adjoining the eye and the broad apex ivory-white, the latter interrupted by a median vitta forked at apex and a small broken spot half way between this and the black ocelli. Face irrorate with fuscous points which become confluent on the front and base of the cheeks and omit the sides of the clypeus, a vitta on the loræ and another on the cheeks above its suture; pale angled line on the base of the front reduced to a small transverse spot less conspicuous than in brevis. Pronotum rather dark with the five pale vittæ distinct. Scutellum tinged with fulvous with a deeper fulvous mark within the lateral angles, the margin with five white spots. Elytra with strong nervures and recticulations, the latter forming a longitudinal median vitta in the anteapical areoles; apex infuscated with the extreme edge white as far as the outer areole; costa crossed by about ten oblique veinlets; the white areolar spots distinct. Beneath and legs varied with pale and fuscous; the disk of the pleural pieces and base of the venter infuscated. The female is paler but with all the markings indicated.

Described from one female and two males from Prof. Herbert Osborn and taken at Los Amates, Guatemala, January 17 th and February 28th, 1905, by Prof. J. S. Hine. This can be confused with no species but brevis from which it may be 
distinguished by its larger size, broader form, shorter and more rounded vertex, the brown vittæ in the anteapical areoles, the longer male pygofers, and the angle on the margin of the last ventral segment of the female. It has somewhat the aspect of scriptus but is very distinct in having a much shorter vertex, in the form of the last ventral segment of the male and in the more angled valve.

\section{Platymetopius brevis Van Duzee.}

Bul. Buf. Soc. Nat. Sci, viii, No. 5, p. 66, 1907.

This tiny species is very close to osborni but it averages a little smaller, the vertex is a little more angled, the transverse vitta is crowded close to the anterior margin of the vertex and consists of a pale cloud against each ocellus which may be obscurely connected to a pale basal mark either side of the middle. The anterior edge is white and calloused and is nearly or quite twice interrupted on either side forming five conspicuous white marginal spots. The general colors in this species are pale, largely obliterating the white areolar spots on the elytra. It has been found only on the island of Jamaica, unless a series from California in the Ball collection belong here.

\section{Platymetopius fuscifrons Van Duzee.}

Bu1. Buf. Soc. Nat. Sci. v., p. 206, 1894.

Platymetopius abruptus Ball, Ent. News, xx., p. 165, 1909.

This is very distinct from any other known dark-faced species by the short transverse male plates and the short truncated last ventral segment of the female. In the male the front is almost black; the vertex is a little more than rightangled at apex and is obscurely marked, with the white apical line distinct. The male is deeply colored as in frontalis while the female seems to be paler than the female of that species, but in both sexes the white areolar spots are well developed. I have been unable to detect any characters by which to distinguish abruptus, the type of which Dr. Ball has kindly sent me for examination, from fuscifrons. This species inhabits Arizona and California.

\section{Platymetopius modestus Stal.}

Of. Vet. Akad. Forh., xi, p. 255, 1854.

This species has not been recognized by later students and from the short description I am unable to place it in my synoptical table. I append a copy of Stal's description: 
"Vertice thoraceque flavis, illo apicem versus concavo, longitudinaliter anguste nigrolineato, hoc basi virescente; hemelytris dilute virescentibus, nervis flavescentibus, margine costali albido-subhyalino; subtus dilute flavotestaceus. Long. 8, lat. 2 millim.-American septentrionalis."

\section{Platymetopius tenuifrons Baker.}

Can. Ent. xxxii, p. 50, 1900.

The type of this species was received too late for its inclusion in the synoptical table. It belongs to the group of brownfaced species and really comes nearest to verecundus from which it differs at once by its much larger size and the still longer vertex. It has somewhat the aspect of the female oregonensis but the vertex is longer, broader, and more rounded at tip. The elytral reticulations and areolar spots are finer but distinct; the general color is more cinereous than fulvous; the front is fuscous-brown irrorated with paler and becomes darker or almost piceous at the pointed base below the short but distinct and acutely angled white line, and the lower surface of the body is varied with pale and brown. The last ventral segment of the male is about as long as the third and is broadly subangularly excavated; valve rather short and broadly rounded; plates broad-triangular and shorter than the valve. The pale pronotal vittæ are obvious but not conspicuous and the vertex is blackened on the immediate apex with a white point at tip and a pale marginal mark on either side and another half way to the eye. The unique male type was taken in November at Chapada, Brazil. 


\section{$2 \mathrm{BHL}$ Biodiversity Heritage Library}

Van Duzee, Edward P. 1910. "A Revision of the American Species of Platymetopius." Annals of the Entomological Society of America 3, 214-231. https://doi.org/10.1093/aesa/3.3.214.

View This Item Online: $\underline{\text { https://www.biodiversitylibrary.org/item/38713 }}$

DOI: https://doi.org/10.1093/aesa/3.3.214

Permalink: https://www.biodiversitylibrary.org/partpdf/193749

\section{Holding Institution}

Smithsonian Libraries

\section{Sponsored by}

Smithsonian

\section{Copyright \& Reuse}

Copyright Status: NOT_IN_COPYRIGHT

This document was created from content at the Biodiversity Heritage Library, the world's largest open access digital library for biodiversity literature and archives. Visit BHL at https://www.biodiversitylibrary.org. 